Abstract-A male whale shark (Rhincodon typus) has been kept in captivity at the Okinawa Churaumi Aquarium, Japan, for 23 years, providing a rare opportunity to observe sexual maturation of a male. In 2012 , when the individual was 8.5 $\mathrm{m}$ in total length (TL), the claspers began to elongate, and the distal ends of the claspers changed into cauliflower-shaped forms. These morphological changes in the claspers were completed in 11 months. Plasma concentrations of sex hormones (testosterone and progesterone) increased in association with clasper elongation. After elongation, additional movements, including the adduction and crossing of claspers, were displayed, and a whitish fluid, which may have been semen, was discharged through the clasper grooves, indicating that the male was functionally mature after clasper elongation. These observations indicate that this captive whale shark reached maturity when it was $8.5 \mathrm{~m}$ TL and over 25 years in age. This size at maturity is consistent with observations in the wild. However, maturity in this individual captive animal may have occurred later than has been previously reported in nature.

Manuscript submitted 7 September 2018. Manuscript accepted 11 April 2019.

Fish. Bull. 117:78-86 (2019).

Online publication date: 26 April 2019. doi: 10.7755/FB.117.1-2.9

The views and opinions expressed or implied in this article are those of the author (or authors) and do not necessarily reflect the position of the National Marine Fisheries Service, NOAA.

\title{
Sexual maturation in a male whale shark (Rhincodon typus) based on observations made over 20 years of captivity
}

\author{
Rui Matsumoto (contact author) 1,2 \\ Yosuke Matsumoto ${ }^{1}$ \\ Keiichi Ueda ${ }^{1,2}$ \\ Miwa Suzuki ${ }^{3}$ \\ Kiyoshi Asahina ${ }^{3}$ \\ Keiichi Sato ${ }^{1,2}$ \\ Email address for contact author: r-matsumoto@okichura.jp \\ 1 Okinawa Churaumi Aquarium \\ Ishikawa 424 \\ Motobu, Okinawa 905-0206, Japan \\ 2 Okinawa Churashima Research Center \\ Ishikawa 424 \\ Motobu, Okinawa 905-0206, Japan \\ ${ }^{3}$ College of Bioresource Sciences \\ Nihon University \\ Kameino 1866 \\ Fujisawa, Kanagawa 252-0880, Japan
}

In the wild, tracking animals, especially migratory aquatic vertebrates, throughout their entire life histories is extremely difficult. Animals often move over vast oceans and have long life spans, sometimes longer than those of humans. Therefore, the life history traits of such animals generally are based on fragmented information, obtained from dead specimens acquired opportunistically.

The process of sexual maturation in the whale shark (Rhincodon typus), the world's largest fish, remains poorly understood because of the difficulties associated with following individuals over long periods of time, both in the wild and in captivity. The Okinawa Churaumi Aquarium, located in Okinawa, Japan, has successfully maintained a whale shark for over 20 years in captivity, providing a unique opportunity to better follow maturation history in this spe- cies (e.g., Uchida et al., 2000; Martin, 2007). This male whale shark, named Jinta, has been exhibited since 1995 at the Ocean Expo Aquarium (renamed the Okinawa Churaumi Aquarium in 2002), representing the longest period of captivity for this species in the world. From 1995 to 2018, the total length (TL) of the animal increased from 4.6 to $8.7 \mathrm{~m}$.

From our study of this shark, we report the process of sexual maturation in the male whale shark, focusing on morphological changes and movements of the claspers, possible semen ejection, and changes in the circulating levels of sex hormones. For male elasmobranchs, the degree of clasper elongation and calcification and increase in sex hormone levels are generally used as indicators of sexual maturation (Gelsleichter and Evans, 2012); however, continuous changes in these indicators 
during the maturation process have never before been documented in whale sharks. This study was based on data from only one individual, but it is still noteworthy because this individual is the only whale shark that has been successfully maintained in captivity for such a long period. Our data provide important insights into the maturation of male whale sharks.

\section{Materials and methods}

\section{Ethics}

This study was conducted as part of the health monitoring for captive animals at the Okinawa Churaumi Aquarium. Animal welfare during rearing was maintained in strict accordance with the ethical guidelines of the Japanese Association of Zoos and Aquariums (JAZA ${ }^{1}$ ), which does not stipulate the experimental procedures to be followed. Therefore, this study did not require separate, specific approval from this association. Maintenance, animal handling, and all procedures associated with this study also were conducted in accordance with the ethical guidelines of Okinawa Churashima Foundation $\left(\mathrm{OCF}^{2}\right)$, which specifies procedures for the care and welfare of higher vertebrates (reptiles, birds, and mammals); these guidelines did not contradict the guidelines of the Japanese Association of Zoos and Aquariums.

\section{Captivity conditions}

The male whale shark is kept at the Okinawa Churaumi Aquarium in an exhibition tank (Kuroshio Tank) with a length, width, and depth of 27,35 , and $10 \mathrm{~m}$. The water in the tank is replaced continuously with natural seawater pumped directly from the East China Sea. The temperature and chemistry of the water in the tank are the same as those in the external environment. The roof of the tank is transparent; therefore, light intensity in the tank reflects that of natural sunlight. The shark is fed $0.5-0.8 \%$ of its body weight in euphausiids and sergestids every day.

\section{Growth}

The TL of the male whale shark was estimated by measuring the length from the snout-tip to the origin of the first dorsal fin (pre-first dorsal fin length [PD1]), to avoid measurement errors caused by lateral tail beats when TL was measured directly. The following equation, from Matsumoto et al. (2017), was used to estimate TL in centimeters:

\footnotetext{
1 JAZA (Japanese Association of Zoos and Aquariums). 1984. Japan Arboretum Aquarium Association ethics summary [Available from website.]

2 OCF (Okinawa Churashima Foundation). 2016. Guide for care and use of laboratory animals of Okinawa Churashima Foundation, 11 p. [Available from Okinawa Churashima Found., Ishikawa 888, Motobu, Okinawa 905-0206, Japan.]
}

$$
\log T L=0.964 \times \log P D 1+0.443 .
$$

The PD1 has been measured underwater directly by 2 scuba divers with a measuring tape, every year since the first year of captivity.

The growth rate was calculated for each growth stage by using segmented regression models (SRMs; Muggeo, 2003; Segura et al., 2013). The growth of elasmobranchs is generally divided into 2 stages, immature (juvenile) and mature (adult) (Jensen et al., 2002), or into 3 stages: immature, maturing, and mature (Saïdi et al., 2009). Therefore, we applied 2 SRMs that estimated 1 or 2 break points (BKs) expected to be turning points of the growth stages, following the method described by Muggeo (2003).

\section{Clasper morphology}

The morphological features of the claspers are used to indicate sexual maturation in elasmobranchs. We calculated the ratio of clasper outer length (CLO) to pelvic inner margin length (P2I) (i.e., CLO:P2I), as described by Compagno (1984). The CLO:P2I is a relative value that represents the degree of elongation from the posterior end of the pelvic fin. The CLO and P2I were analyzed with photogrammetry by using ImageJ, vers. 1.45 (Schneider et al., 2012) to take measurements from photographs of the ventral side of the pelvic region of the shark. The photographs were taken underwater annually from October 2005 through August 2011, and then they were taken monthly until October 2013.

\section{Sex steroid hormones}

The plasma concentrations of testosterone and progesterone ( $\mathrm{T}$ and $\mathrm{P} 4$, respectively) were analyzed by using blood samples. Veterinarians took blood underwater from the radial vein of the pectoral fin, using a syringe with an 18-gauge needle, monthly from May 2008 through December 2013 (Ueda et al., 2017). Blood samples were then transferred to a blood-collection vacuum tube treated with heparin (VP-H050K ${ }^{3}$, Terumo Corp., Tokyo, Japan). After centrifugation (3000 rpm for 15 min), plasma was collected and immediately stored at $-80^{\circ} \mathrm{C}$ for subsequent hormonal analysis. After thawing, the plasma was mixed with diethyl ether, and steroids were extracted by using a common procedure (Suzuki et al., 1998). The extract was diluted 2.5 fold with $0.05 \mathrm{M}$ Tris-HCl ( $\mathrm{pH}$ 7.75) buffer solutions, so that it could be used for measurements. The plasma concentrations of both steroid hormones were determined through time-resolved fluorescent antibody analysis.

We compared the average blood levels of the hormones among the 3 observable developmental periods of the clasper: short (clasper tips and posterior margin of pelvic fins are at the same horizontal position), elon-

\footnotetext{
${ }^{3}$ Mention of trade names or commercial companies is for identification purposes only and does not imply endorsement by the National Marine Fisheries Service, NOAA.
} 


\section{Table}

Fitted parameters from 2 segmented regression models (SRMs) for estimating the growth of the captive male whale shark (Rhincodon typus) at the Okinawa Churaumi Aquarium in Okinawa, Japan. The SRMs used 1 or 2 break points (BKs) expected to be turning points between the 3 growth stages: immature, maturing, and mature. The average monthly changes in growth of body length, during the immature stage $\left(\alpha_{1}\right)$, during the mature stage in the model with 1 BK or the maturing stage in the model with $2 \mathrm{BKs}\left(\alpha_{2}\right)$, and during the mature stage in the model with $2 \mathrm{BKs}\left(\alpha_{3}\right)$, are given with standard errors of the means (SEs). The turning points from the immature to mature stage in the 1-BK model (BK $)_{1}$, from the immature to maturing stage in the 2-BK model $\left(\mathrm{BK}_{1}\right)$, and from the maturing to mature stage in the 2-BK model $\left(\mathrm{BK}_{2}\right)$ are given with $95 \%$ confidence intervals (CI). $r^{2}=$ coefficient of determination.

\begin{tabular}{lcccccrc}
\hline & \multicolumn{3}{c}{ Slopes } & & & \\
\cline { 2 - 3 } & $\alpha_{1}(\mathrm{SE})$ & $\alpha_{2}(\mathrm{SE})$ & $\alpha_{3}(\mathrm{SE})$ & $\mathrm{BK}_{1}(95 \% \mathrm{CI})$ & $\mathrm{BK}_{2}(95 \% \mathrm{CI})$ & Intercept (SE) & $r^{2}$ \\
\hline Model with 1 BK & $2.243(0.072)$ & $0.467(0.320)$ & - & $170.5(154.5-186.4)$ & - & $449.9(8.2)$ & 0.994 \\
Model with 2 BKs & $2.281(0.086)$ & $1.375(0.428)$ & $0.050(0.729)$ & $149.7(117.8-181.7)$ & $195.6(162.8-228.3)$ & $447.8(8.6)$ & 0.993
\end{tabular}
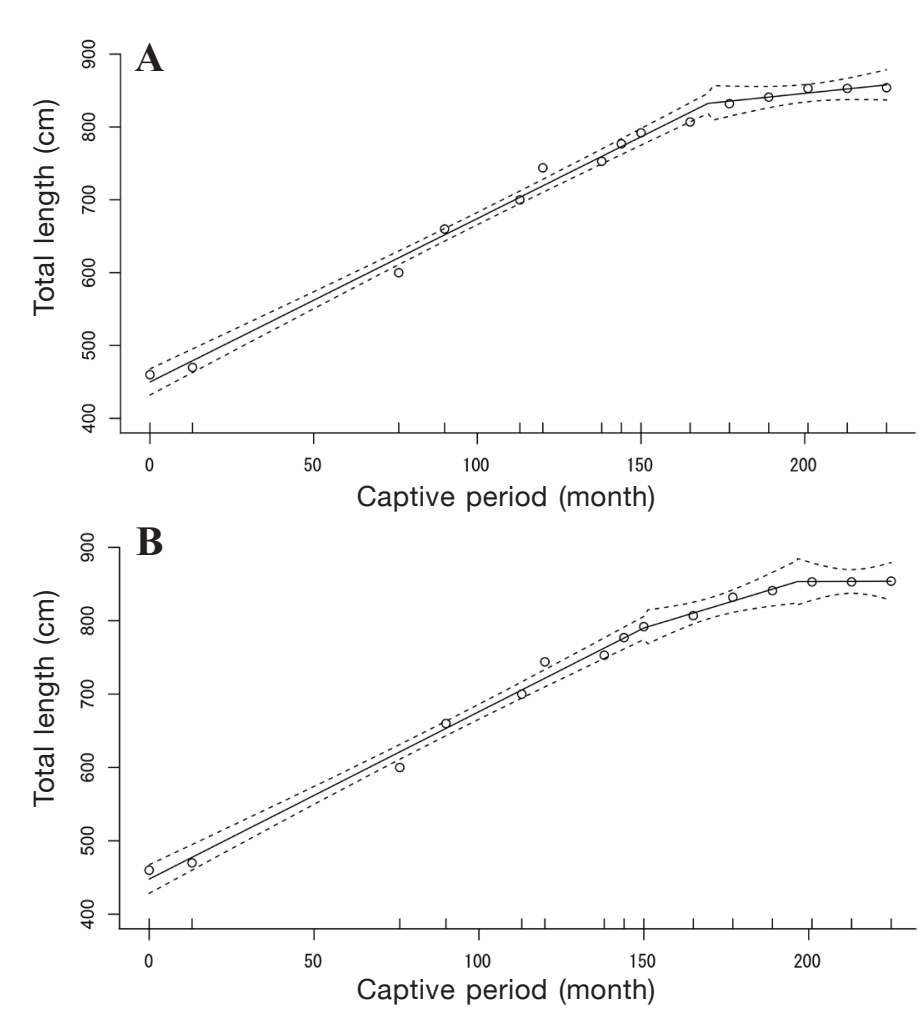

Figure 1

Change in monthly body length of a male whale shark (Rhincodon typus) in captivity at the Okinawa Churaumi Aquarium in Okinawa, Japan, given in centimeters in total length and represented by segmented regression models (SRMs) with (A) 1 and (B) 2 break points. The dotted lines indicate the 95\% confidential intervals. The data used in the SRMs were collected from March 1995 through December 2013. gating (claspers extending behind the posterior margin of pelvic fins), and completed (claspers no longer extending). Statistical analyses were conducted by using the nonparametric Kruskal-Wallis test followed by the nonparametric Steel-Dwass post-hoc test. The relationship between hormone levels and water temperature also was tested by using a regression analysis. Measurements are reported as means with standard errors (SEs), unless otherwise noted.

\section{Results}

\section{Growth}

According to the SRM that used $1 \mathrm{BK}$, the average growth rate for body length (slope) from March 1995 through May 2009 was $2.24 \mathrm{~cm} /$ month (SE 0.07) (Fig. 1A, Table). During this period, the TL increased from 460 to $832 \mathrm{~cm}$. The average growth rate between May 2009 and December 2013 decreased to $0.47 \mathrm{~cm} /$ month (SE 0.32), ํwith TL changing from 832 to $854 \mathrm{~cm}$. Based on the estimates from the SRM that used $2 \mathrm{BKs}$ (Fig. 1B), the average monthly growth from March 1995 through August 2007 was $2.28 \mathrm{~cm}$ (SE 0.07), with TL increasing from 460 to $789 \mathrm{~cm}$ (Table). From August 2007 through June 2011, the growth rate was $1.38 \mathrm{~cm} /$ month (SE 0.43) with TL changing from 789 to $852 \mathrm{~cm}$. The growth rate from June 2011 through December 2013 was $0.05 \mathrm{~cm} / \mathrm{month}$ (SE 0.73) with TL increasing from 852 to $854 \mathrm{~cm}$. Both SRMs revealed that the individual grew in length rapidly until it reached approximately $800 \mathrm{~cm}$ TL. Considering annual growth in TL, the whale shark grew from $460 \mathrm{~cm}$ to $>800 \mathrm{~cm}$ at a rate of $26.9 \mathrm{~cm} /$ 


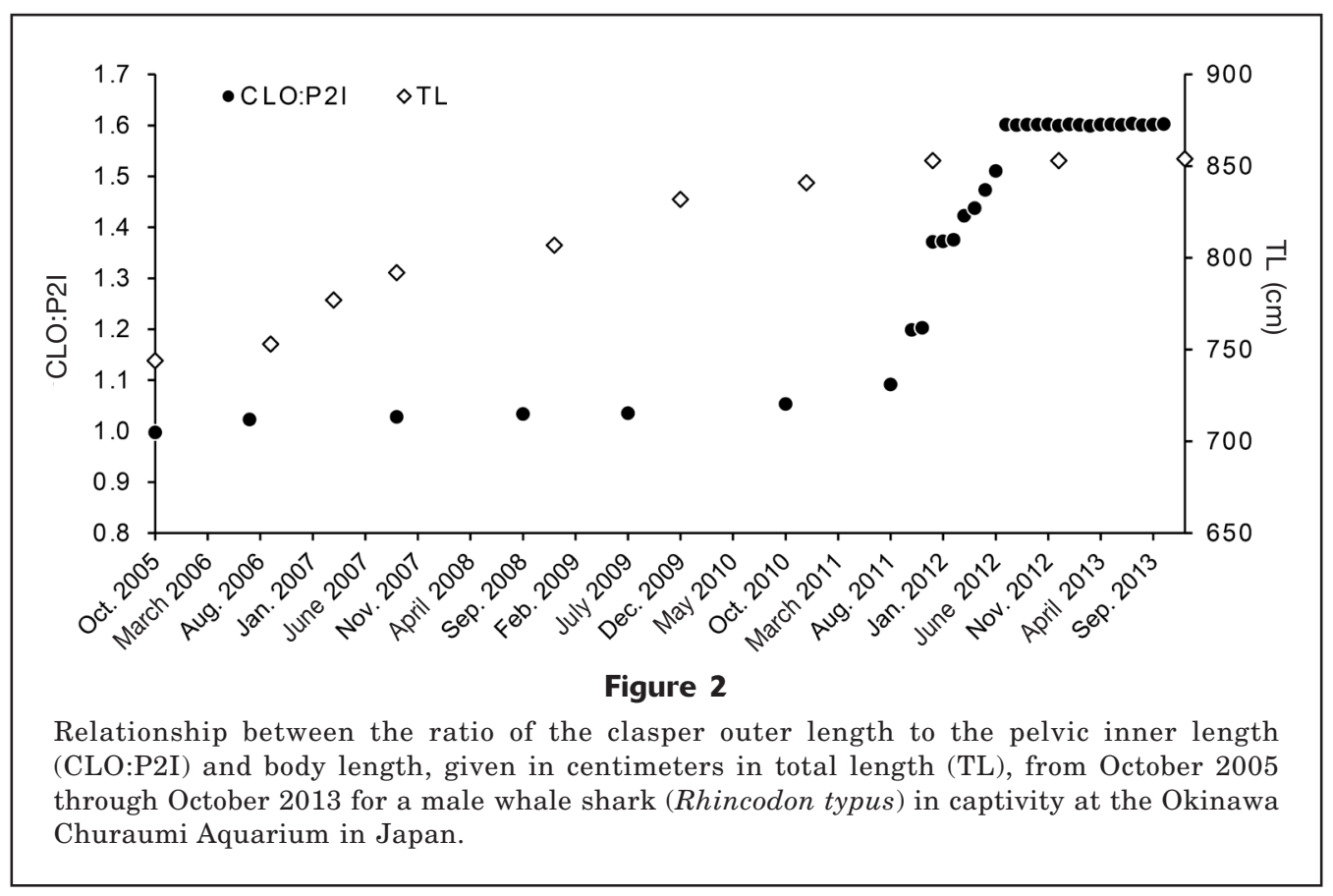

year (1-BK model) or $27.4 \mathrm{~cm} /$ year $(2-$ BK model) from 1995 through 2008; after that time period, the growth rate decreased to $0.6-5.6 \mathrm{~cm} /$ year.

\section{Clasper development and functionality}

Clasper elongation was complete in 11 months (Fig. 2). Before August 2011, CLO:P2I was almost constant (1.00-1.09). After the claspers began to elongate posteriorly beyond the tip of the pelvic fin, CLO:P2I increased to 1.60 by July 2012 ; then this elongation ended, and the CLO:P2I remained constant.

The shape of the claspers changed as the claspers elongated (Fig. 3). Cauliflower-shaped tissues were formed at the distal ends of the claspers, and cartilage associated with the rhipidion (small cartilaginous elements located at the distal end of the clasper) was observed along clasper grooves.

The clasper became functional during a period of rapid elongation with skeletal development of the rhipidion. The whale shark began to display a new behavior in April 2012. The animal turned upside down, to an inverted position, while crossing both claspers simultaneously (Fig. 4, Suppl. Video). The tips of both claspers were spread along the groove and inflected

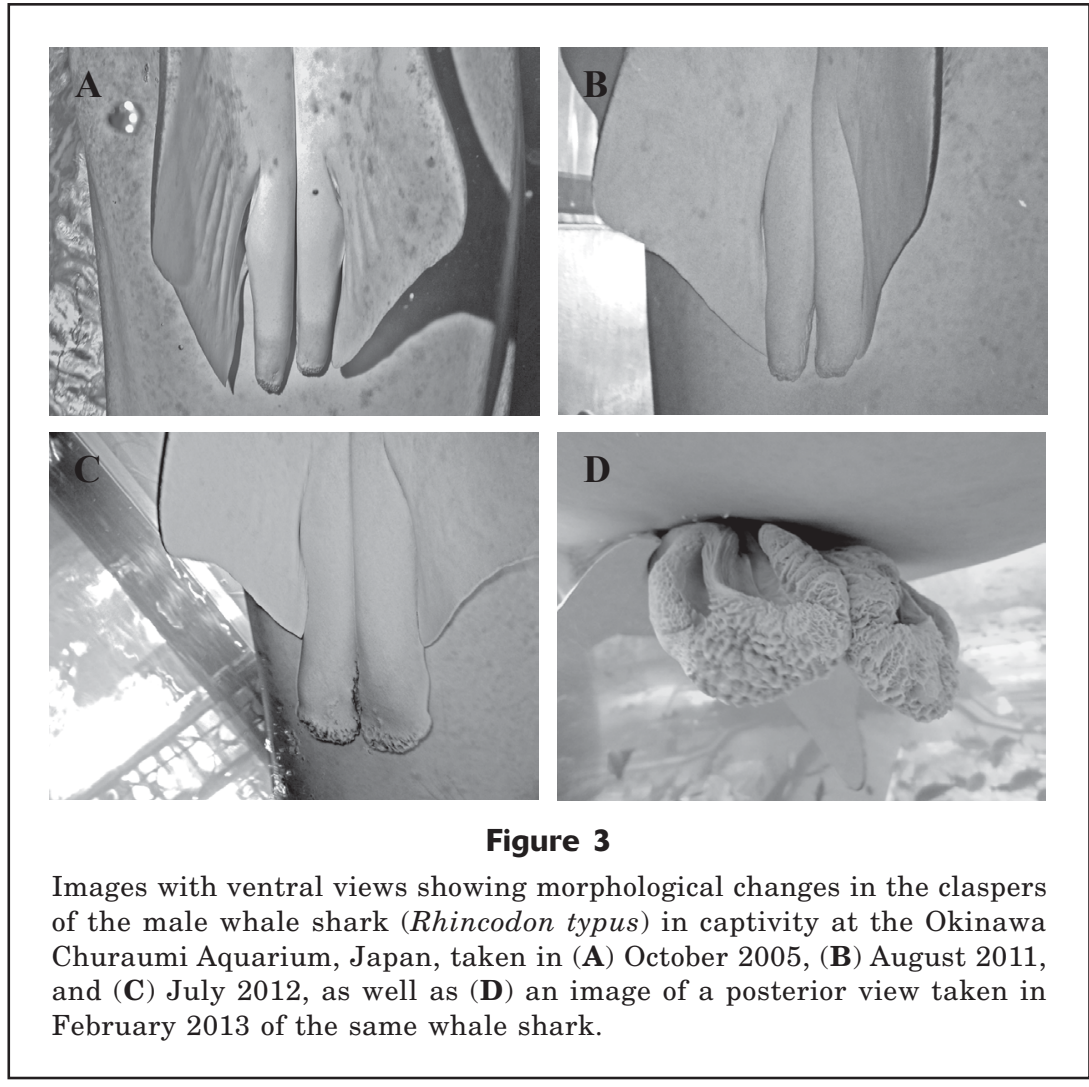




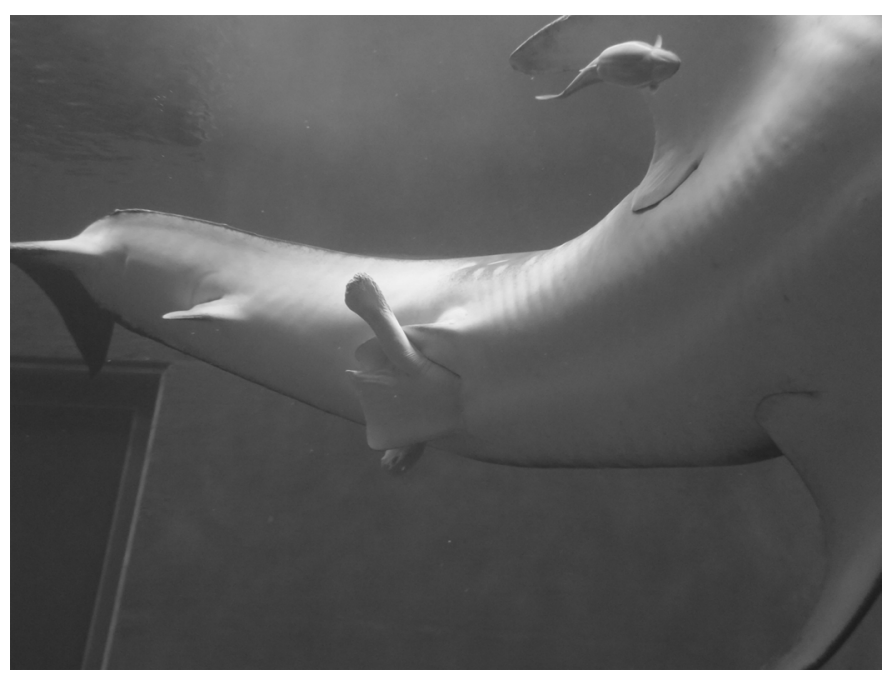

Figure 4

Image with a ventral view of the rotational behavior of the clasper of the male whale shark (Rhincodon typus) in captivity at the Okinawa Churaumi Aquarium, Japan, taken in June 2012. ing and completed periods (Steel-Dwass test: $P<0.01$ for both periods). However, there were no significant differences in $\mathrm{T}$ levels between the elongating and completed periods (SteelDwass test: $P=0.95$ ). Concentrations of $\mathrm{P} 4$ were also lower in the short period than in the completed period (Steel-Dwass test: $P=0.03$ ), although there were no significant differences in P4 levels between the short and elongating periods $(P=0.23)$ or between the elongating and completed periods $(P=0.82)$.

There were significant relationships between water temperature and concentrations of $\mathrm{T}$ (coefficient of determination $\left[r^{2}\right]=0.42$, $P<0.01)$ and $\mathrm{P} 4\left(r^{2}=0.26, P<0.01\right)$ during the short period; whereas, these relationships were not significant during the elongating ( $\mathrm{T}$ : $\left.r^{2}=0.06, P=0.59 ; \mathrm{P} 4: r^{2}=0.14, P=0.40\right)$ and completed (T: $r^{2}=0.14, P=0.17 ; \mathrm{P} 4: r^{2}=0.01, P=0.78$ ) periods (Fig. 7).

\section{Discussion}

Abrupt clasper elongation and increased levels of sex hormones observed in the male whale dorsally while they were crossed. The clasper that was placed on the top of the other varied among events, and both claspers had the top position interchangeably. In addition, starting in August 2012, a white milky fluid was released from the claspers when this behavior was displayed (Suppl. Video). However, it was not possible to confirm whether this fluid was semen because it dispersed and became diffused in the tank immediately after release.

\section{Changes in hormonal levels}

Changes in plasma concentrations of $\mathrm{T}$ and $\mathrm{P} 4$ were recorded among the 3 observable developmental periods of clasper development (Fig. 5). There were minimal changes in the concentrations of $\mathrm{T}$ and $\mathrm{P} 4$ during a short period (from May 2008 to July 2011), with mean $\mathrm{T}$ concentrations of $6.23 \mathrm{ng} / \mathrm{mL}(\mathrm{SE} 0.52$ ) and mean $\mathrm{P} 4$ concentrations of $0.50 \mathrm{ng} / \mathrm{mL}$ (SE 0.08) (Suppl. Table). However, $\mathrm{T}$ concentrations had large fluctuations during the elongating period (from August 2011 to July 2012), ranging between 31.95 and $8.42 \mathrm{ng} / \mathrm{mL}$ with a mean of $18.66 \mathrm{ng} / \mathrm{mL}$ ( $\mathrm{SE} \mathrm{3.06).} \mathrm{In} \mathrm{the} \mathrm{elongating} \mathrm{pe-}$ riod, no change was notable in the levels of $\mathrm{P} 4$, with a mean of $0.79 \mathrm{ng} / \mathrm{mL}$ (SE 0.16) (Suppl. Table). In the completed period (from August 2012 to December 2013), $\mathrm{T}$ and $\mathrm{P} 4$ levels were higher, with means of $36.74 \mathrm{ng} /$ $\mathrm{mL}(\mathrm{SE} \mathrm{9.46)}$ and $1.21 \mathrm{ng} / \mathrm{mL}$ (SE 0.25), respectively, than those in the other 2 periods.

Among the 3 periods of clasper development, there was significant variation in levels of $\mathrm{T}$ (Kruskal-Wallis test: $29.40, P<0.01$ ) and P4 (Kruskal-Wallis test: 7.30, $P=0.03$ ) (Fig. 6). Notably, T concentrations were significantly lower in the short period than in the elongat- shark strongly indicate that the individual is sexually mature. Increases in hormone levels ( $\mathrm{T}$ or $\mathrm{P} 4$ ) associated with male sexual maturation have been reported in various elasmobranchs (Rasmussen and Gruber, 1993), although the mode of action of these hormones remains unclear. Previous studies have hypothesized several functions of sex hormones (such as $\mathrm{T}$ ), including the initiation of mating behavior (Rasmussen and Murru, 1992; Rasmussen and Gruber, 1993), spermiogenesis and spermiation (Tricas et al., 2000; Henningsen et al., 2008), and clasper elongation (Heupel et al., 1999; Sulikowski et al., 2005; Sulikowski et al., 2006; Awruch et al., 2008). Hormone levels were slightly correlated with changes in water temperature when the shark was immature; however, these correlations were not observed during and after the clasper elongation period, and hormone levels were also significantly greater after the shark started to mature sexually. Such patterns have not been previously reported in other elasmobranch species. Further studies are needed to clarify the relationships between hormone levels and water temperature during each growth stage.

Our data allow comparisons between wild and captive whale sharks. The individual studied here was considered mature at $8.5 \mathrm{~m}$ TL. This finding is consistent with the maturation size estimated for wild male whale sharks off the northwestern coast of Australia on the Ningaloo Reef, where $50 \%$ of 275 wild male whale sharks had attained maturity at $8.1 \mathrm{~m}$ TL and $95 \%$ of those sharks had done so by $9.1 \mathrm{~m}$ TL (Norman and Stevens, 2007). We were not able to determine the precise age of maturation in our shark because the shark's age was unknown when he was brought into the aquarium. 


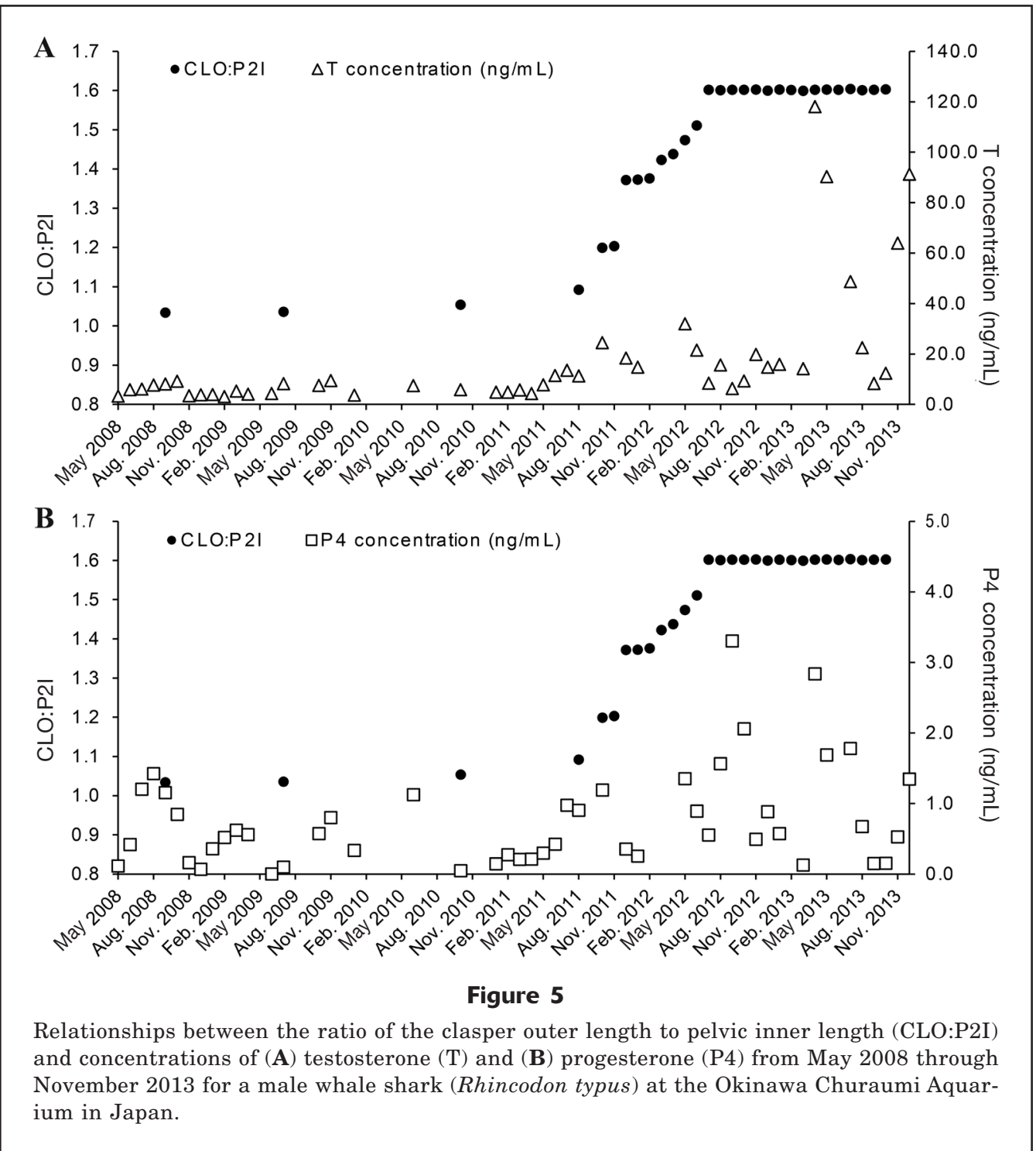

The age of live elasmobranchs can be estimated only by using growth models. Two studies have reported growth curves for the whale shark. Wintner (2000) estimated the ages of 15 dead whale sharks by counting the number of growth bands in vertebrae, assuming that a single pair of growth bands corresponds to 1 year, and generated a growth curve of this species. By using that growth curve, the age of our shark at capture (at a size of $460 \mathrm{~cm}$ TL) was estimated to be 10 or 14 years old. More recently, Hsu et al. (2014) provided new growth curves using a greater sample size $(n=92)$ of species collected from the population in the northwestern Pacific Ocean. They estimated 2 growth curves on the basis of growth bands being deposited either once or twice a year, and they concluded that the band pairs were formed twice a year. The growth curve provided by Hsu et al. (2014) is likely applicable to estimate the age of our shark at capture because the shark was taken from the same region.

Based on the growth curve of Hsu et al. (2014), the age of our shark at the time of capture was estimated to be 7.6 years. Consequently, the estimated age at the time that clasper elongation ceased was 24.9 years. This result indicates that sexual maturation of our shark occurred later than the age at maturity estimated for wild individuals in the Indo-Pacific region (17 years old; Hsu et al., 2014). Meanwhile, Perry et al. (2018) estimated that males in the Maldives mature at 25 years, following the methods described by Hsu et al. (2014). This estimation is comparable to our result. The timing of sexual maturity of the whale shark may be associated more closely with size than with chronological age, a notion that is consistent with previous findings (Gelsleichter et al., 2002); however, further investigations are needed. 


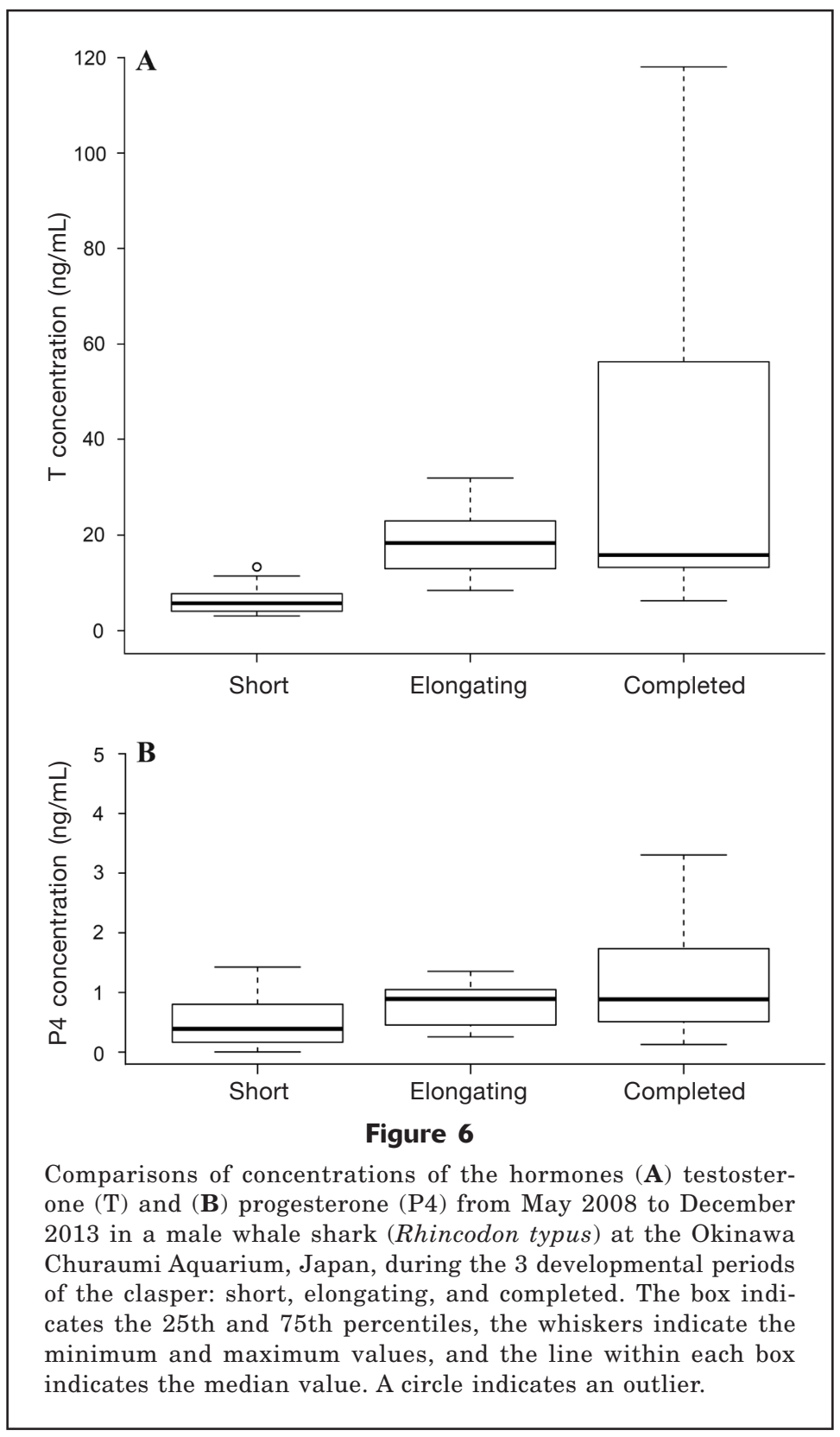

The results of this study indicate that morphological and functional changes in the claspers during maturation occurred over a relatively short time, less than 1 year, in our shark. The animal began to display new clasper movements during the period of rapid clasper growth, behavior that has hitherto not been reported. These movements have been observed during the mating season in other elasmobranchs, including the tawny nurse shark (Nebrius ferrugineus), zebra shark (Stegostoma fasciatum), bull shark (Carcharhinus leucas), sandbar shark (C. plumbeus), and dasyatid rays (senior author, unpubl. data), and they sometimes occur in the absence of females (Ritter and Compagno, 2013). Moreover, a white milky fluid, which we suspect to be semen, was released from the tip of the claspers as the claspers crossed. Based on these observations, it is likely that the functional maturation of the claspers occurs in parallel with morphological changes.

In summary, observations of a captive male whale shark made over a period of 20 years have improved our understanding of the process of sexual maturation in this species. Maturation was associated with increased plasma concentrations of $\mathrm{T}$ and $\mathrm{P} 4$ and the rapid morphogenesis and functioning of claspers. Additional studies involving both captive and wild individu- 


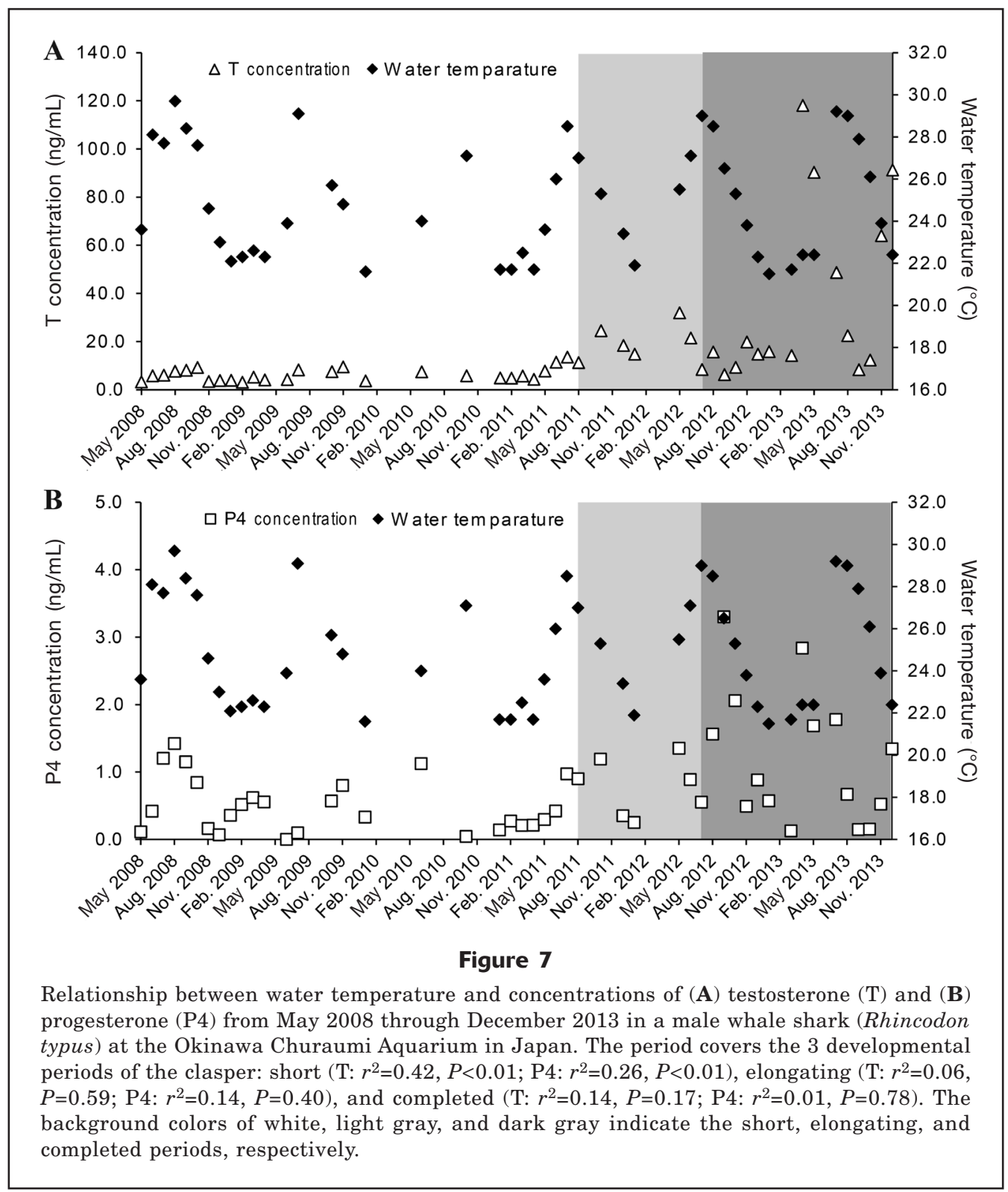

als are needed to further advance the biology of the well-known but mysterious whale shark.

\section{Acknowledgments}

We express our gratitude to the Yomitan Fisheries Cooperative for collecting the whale shark used for these observations. We acknowledge H. Miyahara for providing us the opportunity to perform this research. We thank both A. Uno and K. Aoki from the Nihon University, for assistance with laboratory analyses, and R. Nozu, T. Tomita, and Y. Obayashi for their comments on this manuscript. We recognize S. Uchida, M. Toda, M. Nakazato, A. Yamashiro, K. Murakumo, and other colleagues for their valuable information and advice.

\section{Literature cited}

Awruch, C. A., N. W. Pankhurst, S. D. Frusher, and J. D. Stevens.

2008. Endocrine and morphological correlates of reproduction in the draughtboard shark Cephaloscyllium laticeps (Elasmobranchii: Scyliorhinidae). J. Exp. Zool. 309A:184-197. Crossref

Compagno, L. J. V.

1984. FAO species catalogue. Vol. 4. Sharks of the world: an annotated and illustrated catalogue of shark species known to date. Part 1-Hexanchiformes to Lamniformes. FAO Fish. Synop. 125, 249 p. FAO, Rome.

Gelsleichter, J., and A. N. Evans.

2012. Hormonal regulation of elasmobranch physiology. In Biology of sharks and their relatives, $2^{\text {nd }}$ ed. $(\mathrm{J}$. 
C. Carrier, J. A. Musick, and M. R. Heithaus, eds.), p. 313-348. CRC Press, Boca Raton, FL.

Gelsleichter, J., L. E. L. Rasmussen, C. A. Manire, J. Tyminski, B. Chang, and L. Lombardi-Carlson.

2002. Serum steroid concentrations and development of reproductive organs during puberty in male bonnethead sharks, Sphyrna tiburo. Fish Physiol. Biochem. 26:389-401. Crossref

Henningsen, A. D., F. L. Murru, L. E. L. Rasmussen, B. R. Whitaker, and G. C. Violetta.

2008. Serum levels of reproductive steroid hormones in captive sand tiger sharks, Carcharias taurus (Rafinesque), and comments on their relation to sexual conflicts. Fish Physiol. Biochem. 34:437-446. Crossref

Heupel, M. R., J. M. Whittier, and M. B. Bennett.

1999. Plasma steroid hormone profiles and reproductive biology of the epaulette shark, Hemiscyllium ocellatum. J. Exp. Zool. 284:586-594. Crossref

Hsu, H. H., S. J. Joung, R. E. Hueter, and K. M. Liu.

2014. Age and growth of the whale shark (Rhincodon typus) in the north-western Pacific. Mar. Freshw. Res. 65:1145-1154. Crossref

Jensen, C. F., L. J. Natanson, H. L. Pratt Jr., N. E. Kohler, and S. E. Campana.

2002. The reproductive biology of the porbeagle shark (Lamna nasus) in the western North Atlantic Ocean. Fish. Bull. 100:727-738.

Martin, R. A.

2007. A review of behavioural ecology of whale sharks (Rhincodon typus). Fish. Res. 84:10-16. Crossref

Matsumoto, R., M. Toda, Y. Matsumoto, K. Ueda, M. Nakazato, K. Sato, and S. Uchida.

2017. Notes on husbandry of whale sharks, Rhincodon typus. In Elasmobranch husbandry manual II: recent advances in the care of sharks, rays and their relatives (M. Smith, D. Warmolts, D. Thoney, R. Hueter, M. Murray, and J. Ezcurra, eds.), p. 15-22. Ohio Biol. Surv., Columbus, $\mathrm{OH}$.

Muggeo, V. M. R.

2003. Estimating regression models with unknown breakpoints. Stat. Med. 22:3055-3071. Crossref

Norman, B. M., and J. D. Stevens.

2007. Size and maturity status of the whale shark (Rhincodon typus) at Ningaloo Reef in Western Australia. Fish. Res. 84:81-86. Crossref

Perry, C. T., J. Figueiredo, J. J. Vaudo, J. Hancock, R. Rees, and M. Shivji.

2018. Comparing length-measurement methods and estimating growth parameters of free-swimming whale sharks (Rhincodon typus) near the South Ari Atoll, Maldives. Mar. Freshw. Res. 69:1487-1495. Crossref

Rasmussen, L. E. L., and F. L. Murru.

1992. Long-term studies of serum concentrations of reproductively related steroid hormones in individual captive carcharhinids. Aust. J. Mar. Freshw. Res. 43:273281. Crossref

Rasmussen, L. E. L., and S. H. Gruber.

1993. Serum concentrations of reproductively-related circulating steroid hormones in the free-ranging lemon shark,
Negaprion brevirostris. Environ. Biol. Fish. 38:167174. Crossref

Ritter, E. K., and L. J. V. Compagno.

2013. Clasper flaring: maintenance behavior, or a normally hidden feature of male whitetip reef sharks, Triaenodon obesus? Open. Fish Sci. J. 6:10-12. Crossref

Saïdi, B., M. N. Bradaï, and A. Bouaïn.

2009. Reproductive biology and diet of Mustelus punctulatus (Risso, 1826) (Chondrichthyes: Triakidae) from the Gulf of Gabès, central Mediterranean Sea. Sci. Mar. 73:249-258. Crossref

Schneider, C. A., W. S. Rasband, and K. W. Eliceiri.

2012. NIH Image to ImageJ: 25 years of image analysis. Nat. Methods 9:671-675. Crossref

Segura, A. M., A. C. Milessi, R. Vögler, F. Galván-Magaña, and V. Muggeo.

2013. The determination of maturity stages in male elasmobranchs (Chondrichthyes) using a segmented regression of clasper length on total length. Can. J. Fish. Aquat. Sci. 70:830-833. Crossref

Sulikowski, J. A., P. C. W. Tsang, and W. H. Howell.

2005. Age and size at sexual maturity for the winter skate, Leucoraja ocellata, in the western Gulf of Maine based on morphological, histological and steroid hormone analyses. Environ. Biol. Fish. 72:429-441. Crossref

Sulikowski, J. A., J. Kneebone, S. Elzey, J. Jurek, W. H. Howell, and P. C. W. Tsang.

2006. Using the composite variables of reproductive morphology, histology and steroid hormones to determine age and size at sexual maturity for the thorny skate Amblyraja radiata in the western Gulf of Maine. J. Fish Biol. 69:1449-1465. Crossref

Suzuki, M., T. Tobayama, E. Katsumata, M. Yoshioka, and K. Aida.

1998. Serum cortisol levels in captive killer whale and bottlenose dolphin. Fish. Sci. 64:643-647. Crossref

Tricas, T. C., K. P. Maruska, and L. E. L. Rasmussen.

2000. Annual cycles of steroid hormone production, gonad development, and reproductive behavior in the Atlantic stingray. Gen. Comp. Endocrinol. 118:209-225. Crossref

Uchida, S., M. Toda, Y. Kamei, and H. Teruya.

2000. The husbandry of 16 whale sharks Rhincodon typus, from 1980 to 1998 at the Okinawa Expo Aquarium. In Abstracts of the American Elasmobranch Society 16th Annual Meeting; La Paz, Mexico, 14-20 June. [Available from website.]

Ueda, K., M. Yanagisawa, K. Murakumo, Y. Matsumoto, K. Sato, and S. Uchida.

2017. Physical examination, blood sampling, and sedation of large elasmobranchs. In Elasmobranch husbandry manual II: recent advances in the care of sharks, rays and their relatives (M. Smith, D. Warmolts, D. Thoney, R. Hueter, M. Murray, and J. Ezcurra, eds.), p. 255262. Ohio Biol. Surv., Columbus, Ohio.

Wintner, S. P.

2000. Preliminary study of vertebral growth rings in the whale shark, Rhincodon typus, from the east coast of South Africa. Environ. Biol. Fish. 59:441-451. Crossref 